\title{
The Missing Curriculum Link: Personal Financial Planning
}

Adolph A. Neidermeyer, West Virginia University, USA

Presha E. Neidermeyer, West Virginia University, USA

\begin{abstract}
With increasing personal and business financial challenges facing today's professionals, we, as business school faculty, have a responsibility to offer the educational background that should enable rising professionals to successfully manage finances. Unfortunately, the results of a recent analysis of curriculum offerings in Personal Financial Planning indicate that we, as faculty, have not fully accepted this responsibility. Only three out of the 131 four-year institutions reviewed have a required Personal Financial Planning course in their curriculums. Quite frankly, we're permitting launching a generation of students who are unprepared to manage both their own and potentially others' financial affairs. With that shortfall of a course offering as a backdrop, we suggest the following content for a required Personal Financial Planning course for all students majoring in Business Administration.
\end{abstract}

Keywords: Personal Financial Planning, Financial Affairs

\section{INTRODUCTION}

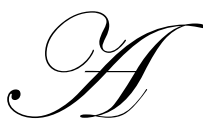

\section{Step One: Establish Your Direction}

New professionals should self-reflect immediately after graduation, hopefully with their new professional position secured, to establish a series of personal goals. We all need a roadmap to focus our attention on the future and on the steps necessary to successfully achieve our desired goals. Without established goals, we may move laterally rather than toward a formulated goal. We reiterate the necessity of, as the personal financial planning texts suggest, the formulation of at least three goals: twelve-month, thirty-six month and sixty-month goals. With goals in place the individual has sequential targets toward which to work.

\section{Step Two: Begin to Manage Your Intellectual Capital}

New professionals should evaluate the efficiency of their initial career choice. The purpose of an individual's initial career choice is to prepare him/her for subsequent promotions within the organization or for a second position elsewhere. Continuing evaluation of the "growth" aspect of your chosen position is necessary because once you're graduated, you're the manager of your "intellectual capital" for the remainder of your career. You've got to remain to the forefront of your profession by growing your intellectual capital through additional education and on-the-job experience In order to maintain your competitive edge in the marketplace.

\section{Step Three: Document Your Current Financial Situation}

Since graduating students will be immediately making choices under their perquisite plan through their employers, the initial requirement is to have an established personal database to enable both selection from among perquisite plan alternatives and the evaluation of subsequent performances. We recommend that each individual 
have documentation of his/her personal financial statement, a detailed listing of assets, liabilities and personal equity, in order to provide a reference for evaluations of future income/investment performances. Additionally, each individual should develop a going-forward budget based on his/her awareness of his or her monthly net income and anticipated initial spending/saving requirements. This suggestion is made to provide the individual with "spending caution" in that each new budget requirement should be profiled to determine if it will "fit" into the existing spending plan of the individual. We want to avoid potentially "financially intrusive" commitments before they're made. The formulation of these two databases will provide the background financial information the individual needs to cautiously move up to their professional-career earning levels.

\section{Step Four: Develop a Written Working Budget}

The formulation of a budget necessitates inclusion of credit management by the individual. It is your responsibility to "correctly use" credit rather than having the credit companies "use" you. Initially, you must know how credit evaluators have profiled you. Before you are considered for employment or apply for credit/a loan, you should check to be certain that the information in your credit report is correct. Please utilize www.annualcreditreport.com to access your credit reports from each of the three national reporting agencies. Once this awareness is in hand, go to www.bankrate.com and review the profiling of available credit cards before you sign up. Request an available line of credit that will be adequate for your normal activities and do not increase this available line unless you really have a need for larger credit availability. Pay all bills on time and, given today's identity theft possibilities, periodically check your credit report. You may review a free report from each of the three credit reporting agencies one each year. Credit utilization is a privilege and you should guard your continuing access to use it throughout your life.

With your credit rating awareness, you should move to the development of a detailed spending plan to guide you in your financial commitments. Online budget websites provide excel spreadsheets to facilitate development of this spending plan. Obviously, you may spend your money as you decide; the caution is to determine the "fit" of any anticipated expenditure into your overall budget before you spend. Make every effort to keep your fixed budget items to a minimum because these expenditures must be met from your available "net" before you can have some fun with your discretionary spending. Give your proposed budget a serious try for at least three months before you alter any of the spending parameters.

\section{Step Five: Protect What You Have}

The next focus for the rising professional is the adequacy of insurance coverages: life, disability, medical, property, long-term care, and liability. Most individuals are underinsured in all areas so this personal evaluation is critical to provide both future benefits and adequate protection of the individual's assets. Our interest in suggesting this review is to have the individual become aware of the coverages which are currently provided through his/her employer and those that must be acquired individually. First, the individual should maximize the coverages available through his/her employment because most if not all are made available without cost or tax implications for the individual. Employer insurance coverages of most importance are disability income, medical and life. Your assessment should determine if coverages are adequate for your unique personal situation. The individuallyacquired insurance coverages of interest would be personal liability and renter's insurance. Auto insurance is assumed because state law requires this coverage. In assessing adequacy of coverage, document the dollar-value of any future loss you might suffer. In order to do this evaluation, you'll need to look at liability settlements in auto accidents in your area. In addition, you'll need to quantify the value of your personal inventory of household items with the existing internal policy limits of coverage in your insurance policy. Insurers know the likely items to be stolen and have limited their dollar coverage of these items on the standard insurance policy. Insurance works if you've determined you've purchased adequate coverage for your potential losses.

\section{Step Six: Put Your Dollars to Work for You}

Once the individual is "protected," we suggest the development of a personal investment plan. Your effort here is simple: decide what you want, when you want it, what it will cost and establish the necessary steps to "get it!" Again, the initial focus is on the availability of investments through the employer's retirement plan in which the 
individual will be a participant unless he/she elects "out." A policy of "screen" before you "select" is suggested to have the individual know that he/she should spend time to become familiar with his/her potential investments before making any selections. Current planning suggestions call for saving/investing as much as possible but at least ten percent of your gross income each year and more when you progress up the income ladder. Once selection has taken place, periodic monitoring is required to assure movement toward designated "investment goals." With the exception of retirement planning, this investing for a specific goal is a very simple exercise of determining what amount needs to be saved over each period to have sufficient monies when the desired item is to be acquired.

\section{Step Seven: Make "Informed" Big Acquisitions}

In addition to your continuing investment plan, you will be making several large acquisitions, vehicles and homes, during your lifetime. We'd like you to be an informed purchaser to enable you to maximize your benefit and minimize your cost. In order to accomplish these goals, you should familiarize yourself with the details of both acquisitions before your buy. A series of websites and checklists serve to highlight the necessary pre-purchasing steps to be completed as you consider each of the acquisitions. These are potentially large dollar commitments for an extended period of time so it is to your advantage to become aware of all the pre-purchase information that's available to permit you to make an "informed" commitment.

\section{Step Eight: Always Remember the Tax Collector}

A backdrop to each of the personal planning efforts is to accomplish the step with minimum tax ramifications. Your charge as a new professional is to either familiarize yourself with the details of tax planning or include in your budget sufficient monies to pay for tax advice in advance of any significant personal planning choices. You clear any tax considerations first to enable all planning steps to be "open" for change if needed. Taxes are an integral part on all transactions.

\section{Step Nine: Get Some Gold for Your Silver-Hair Years}

Retirement and estate planning constitutes another planning focus. These two items are largely ignored by younger professionals because of the assumed time delay before any personal impact is experienced. We suggest that rising professionals take the following steps immediately upon entering the workforce: participate fully in funding your future retirement by saving/investing a minimum of ten percent of your gross salary, always capture any employer "match" of your contributions and consider the establishment of a Roth IRA. For estate purposes, please designate beneficiaries for each of your retirement plans as well as executing a medical power of attorney, a durable power of attorney and at least a simple will. The retirement funding suggestion is made to minimize the financial impact on your going-forward budget. The earlier you begin your retirement funding the less it costs you per month. You've got the best of both worlds in that the cost is lower and you take advantage of the power of compounding because your money earns interest for a longer period of time. The estate suggestions will provide "peace of mind" to you and others because you'll have a plan in place just in case something happens before you think it should. Our suggestion is that you should get "busy" with arrangements well before you/your family have need for them.

\section{Step Ten: Anticipate Life's Bumps}

The final suggestion for the Personal Planning course is to briefly overview some of life's "bumps" which individuals may face. By enumerating these "bumps" in advance, we ask students to consider how they might address the issues. Some of the "bumps" for reflection are co-habitation, marriage, starting a family, starting a business, handling a parent's end of life issues and divorce. Role-playing in these situations causes students to pause and reflect on available approaches to successfully handling these "bumps."

\section{CONCLUSIONS}

Completion of this course in Personal Planning will provide a heads-up for the students before they have to handle these life issues. The immediacy of handling should be facilitated if the individual has seen/thought about 
this situation in advance. We suggest that all students will be better prepared to navigate life's highway with the information provided in this Personal Planning course.

\section{AUTHORS INFORMATION}

Dr. Adolph A. Neidermeyer has been on faculty at West Virginia University for thirty-eight years. He has been recognized numerous times by students and student organizations for his outstanding teaching. Dr. Neidermeyer specializes in taxation and personal financial planning. He offers professional development executive short courses in financial accounting and personal planning issues. His research interests are diversified into the following areas: not-for-profit accounting, tax planning, personal financial planning, and environmental reporting.

Dr. Presha E. Neidermeyer is a faculty member in the Division of Accounting within West Virginia University's College of Business and Economics. She is a behavioral researcher focusing on current events with particular emphasis on the impact of culture on decision-making. She is the co-author of Use What You Have: Resolving the HIV/AIDS Pandemic. Her teaching specialties includes: financial and international accounting. She is an active participant in various organizations benefiting charities in Africa and has led multiple business-student teams to Africa.

\section{REFERENCES}

1. Annual Credit Report.org. "Obtaining your annual credit report." https://www.annualcreditreport.com/cra/index.jsp

2. $\quad$ Bankrate.com. "Credit Cards." http://www.bankrate.com/credit-cards.aspx

3. Certified Personal Financial Planner Board of Standards Inc. "Topic List for CPF Exam." http://www.cfp.net/become/exam.asp 